\title{
Smoking problem in Indonesia
}

\author{
Tjandra Yoga Aditama
}

\begin{abstract}
Abstrak
Kebiasaan merokok merupakan masalah kesehatan pentin g di Indonesia. Sampai $60 \%$ pria Indonesia dan sekitar $4 \%$ perempuan di 11egara kita punya kebiasaan merokok. Kadar tar dan nikotin beberapa rokok kretek ternyata juga cukup tinggi. Selain dampak kesehatan rokok juga punya dampak buruk pada ekonomi, baik tingkat individu maupun keluarga. Dari sudut kesehatan, kendati data morbiditas dan mortalitas berskala nasional sulit didapat, data dari berbagai kota menunjukkan timbulnya berbagai penyakit akibat rokok seperti kanker paru, PPOK, gangguan pada janin dan sebagainya. Masalahnya lagi, kebiasaan merokok telah dimulai usia sangat muda di Indonesia. Pada tulisan ini disampaikan ju ga hambatan-hambatan dalam prog ram penanggulangan masalah merokok serta hal-hal yang perlu dilakukan untuk meningkatkan program penanggulangan yang ada. (Med J lndones 2002; 11: 56-65)
\end{abstract}

\begin{abstract} Indonesia. (Med J Indones 2002; 11: 56-65)

Keywords: smoking, Indonesia, impact

The Republic of Indonesia, which consists of approxi mately 17,000 islands, had a population of 210 million; it is the fourth most populous country in the world after China, India, and the United States with hundred s of ethnic groups and language I dialects being practices in the country. An estimated 55.4 million persons (31\% of the population) were living in urban areas in 1990, compared with 73.4 million (36\% of the population) in $1997 \cdot-2 \cdot{ }^{3}$ All of these factors complicate tobacco-control measures in Indonesia .
\end{abstract}

Smoking is an important public health problem in Indonesia. Up to 60\% of male adult population as well as about $4 \%$ offemal e adult population are smokers. In fact, some of Indonesian kretek cigarettes have quite high tar and nicotine content. Besides health effect, smoking habit also influence economic status of the individuals as well as the family. In health point of view, even though reliable nation wide morbidity and mortality data are scarce, report from various cities showed smoking related diseases, such as lung cancer, $C O P D$, effect of pregnan cy, etc. Other problem is a fact that smoking habit start quite in early age in Indonesia. This article also describe fa ctors complicate smoking control program as well as several things to be done to strengthen smoking control prog ram in

\section{Smoking Pattern}

Table I compiles the results from several studies on smoking behavior in Indonesia. The percentage of current smokers among males ranges from $30.2 \%$ to

Pulmonolog y Department Faculty of Medicine University of Indonesia I Persahabatan Hospital, Jakarta, Indonesia
$72 \%$, with the highest percentage belong to the drivers of public buses in Jakarta. Among females, the percentage ranges from $1.5 \%$ to $9.7 \%$.

The Indonesian Smoking Control Foundation ("LM 3") compiled a meta-analysis study on smoking patterns $\mathrm{m} \mathrm{I}^{\mathrm{d}}$ onesía. ${ }^{14}$

The conclusions of the meta-analysis study performed by "LM3" included the following: ${ }^{14}$

1. The studies found that $59.04 \%$ of males over ten years of age in the 14 provinces in Indonesia were currently smoking. Among females over 10 years of age, 4,83\% were current smokers.

2. There was a negative correlation between the level of education and the percentage of current smokers.

3. On average, current male smokers consume almost ten cigarettes each day, while female current smokers consume around three cigarettes each day. 
4. Among both current and former smokers, males or females, the freq uency of smoking was still fairly mild, less than 200 score indexed by mu ltiplication of nu mber of cigarettes and length of smoking.

5. Ex-smokers generally reported smoking higher $\mathrm{n}$ u mbers of cigarettes than current smokers. In males it was 13 versus 10 cigarettes daily, and in females it was more significant at 6.2 versus 3 cigarettes daily.

6. The average of ounces of tobacco per week was 0.79 in current users, and 1.42 in ex-users.
7. Clove-flavoured cigarettes ( kretek ) were the favourite choice of smokers in Indonesia. For male current smokers, 84,31\% preferred kretek cigarettes, as did $79,42 \%$ of the female smokers. Similar figures were found in former smokers, as $84,31 \%$ of the males and $72.94 \%$ of the females preferred the clove cigarettes.

8. For both current or former smokers, the age of smoking initiation were quite you ng. Females tend to start to smoke at the older age.

Table I . Percentage of Current Smokers in some studies in Indonesi a

\begin{tabular}{|c|c|c|c|c|c|c|c|}
\hline \multirow[t]{5}{*}{ No. } & Study -year -investigator & Question & $\mathrm{N}$ & Ages & Males & Females & Total \\
\hline & $\begin{array}{l}\text { Survey on Eye and ENT Heal th } 1994- \\
1996 \text { in } 7 \text { Provinces, MOH, Rl }{ }^{4}\end{array}$ & $\begin{array}{l}\text { Do you currently } \\
\text { smoke? }\end{array}$ & 14071 & $\begin{array}{l}\text { J } 0 \text { years } \\
\text { and older }\end{array}$ & $48,34 \%$ & $3,16 \%$ & $22,68 \%$ \\
\hline & $\begin{array}{l}\text { Indonesian Family Life Survey } 1993 \text { m } \\
\text { I } 3 \text { Provi nces }\end{array}$ & $\begin{array}{l}\text { Have you ever } \\
\text { smoked? }\end{array}$ & 14638 & $\begin{array}{l}10 \text { years } \\
\text { and older }\end{array}$ & $67,70 \%$ & $9,70 \%$ & $36,50 \%$ \\
\hline & LD-FEU I, Rand $\mathrm{Co}^{5}$ & & & & & & \\
\hline & $\begin{array}{l}\text { National Household Survey, Module on } \\
\text { Susenas, J 995, in } 5 \text { Provinces, MOH, } \\
\text { RI" }\end{array}$ & $\begin{array}{l}\text { Have you } \\
\text { smoked in the } \\
\text { past month? }\end{array}$ & $65664 \mathrm{HH}$ & $\begin{array}{l}10 \text { years } \\
\text { and older }\end{array}$ & $45,00 \%$ & $1,50 \%$ & $22,90 \%$ \\
\hline 4 & $\begin{array}{l}\text { Prospecti ve Study on Public Health, } \\
\text { Pasar Rebo, Cipayu ng \& Ciracas, East } \\
\text { Jakarta 1993/94, Fae of Public Health } \\
\text { - UI }\end{array}$ & $\begin{array}{l}\text { Does the head of } \\
\text { your house- hold } \\
\text { smoke? }\end{array}$ & 17349 & $\begin{array}{l}\text { Head of } \\
\text { HH (adult) }\end{array}$ & & & $30.20 \%$ \\
\hline 5 & $\begin{array}{l}\text { Smoking And Its Socioeconomic } \\
\text { Aspects In Jakarta, 1981, Soekidjo, } \\
\text { Siregar, Wibowo. Fae. of PH - UI }\end{array}$ & NA & 250 & $\begin{array}{l}10 \text { years } \\
\text { and older }\end{array}$ & & & $64.40 \%$ \\
\hline 6 & $\begin{array}{l}\text { Effect On Smoking Deceased Program } \\
\text { Among The Smoker -Workers In } \\
\text { St.Carol us Hospital, Jakarta, 1995, } \\
\text { Judin. Tanju ng, Fae. of PH - UI" }\end{array}$ & NA & 449 & Adult & $48,00 \%$ & & $48,00 \%$ \\
\hline 7 & $\begin{array}{l}\text { Relationshi p Between Habit On Cloves } \\
\text { Smoking And Dental Destruction, } \\
\text { A mong The Dri vers Of PPD Company } \\
\text { In Jakatta, 1992, } \\
\text { Soetiarto'0 }^{\text {Sol }}\end{array}$ & Do you smoke? & 3386 & Adult & $72 \%$ & & $72 \%$ \\
\hline 8 & $\begin{array}{l}\text { Action on smoking, in: Compi btion of } \\
\text { papers on Cancer Problem (Ku mpulan } \\
\text { Naskah Masalah Kan ker), } \\
\text { Hoepoedio, I } 981^{11}\end{array}$ & NA & 1000 & & & $2,1 \%$ & $64,4 \%$ \\
\hline 9 & $\begin{array}{l}\text { Proportion Of Smokers Among The } \\
\text { Male Employees In The Office Of } \\
\text { Ditjen Bin kesmas, MOH, } 1996 \\
\text { Syafranelsar, Fae. of PH - Ul }\end{array}$ & $\begin{array}{l}\text { Have you ever } \\
\text { smoked? }\end{array}$ & 186 & Ad ult & $50,0 \%$ & & $50,0 \%$ \\
\hline 10 & $\begin{array}{l}\text { Study On Knowledge, Attitude And } \\
\text { Behavior On Smoking, Among The } \\
\text { Pupi ls of Elemen tary School Grades V } \\
\text { And Y I, In East Jakarta 1992, } \\
\text { Shebubakar, Fae of Medicine - Ul }{ }^{13}\end{array}$ & Do you smoke? & 431 & $\begin{array}{l}\text { Grade } 5 \\
\text { and } 6 \\
\text { (Primary } \\
\text { School) }\end{array}$ & & & $12,76 \%$ \\
\hline
\end{tabular}

$(-)$ : Not avai lable $I$ not calcul ated 
The above data show no significant differences when compared with the WHO (1997) estimation, where in Indonesia the prevalence of current smokers was reported to be $53.0 \%$ of the males and $4 \%$ of the females. But it should be noted that the WHO figures were for people over the age of 15 years. ${ }^{15}$

The Indonesia Household Health Survey in 1980 showed that about $54 \%$ of males and about $3 \%$ of the females over ten years of age were regular (daily) smokers. A similar survey carried out in 1986 reported similar prevalence rates (53\% of males, $4 \%$ of females). Other surveys carried out during he 1980s in Lombok, Jakarta, and Yogyakarta reported male prevalence levels of $75 \%, 65 \%$, and $61 \%$, respectivel y, and female prevalence levels less than $5 \%$ (except for Jakarta where $9.8 \%$ of the females are smokers) . Nationally, the prevalence of smoking is approximately $60 \%$ for men and $5 \%$ for women. ${ }^{17}$

According to a 1985 survey in Semarang, 36\% of doctors smoked, as did 79\% of paramedical person nel. Almost all (96\%) of the "peddle rickshaw" drivers in the survey smoked, as did over half (52\%) of government civil servants. A 1992 survey of medical students revealed that $8 \%$ of males and $1 \%$ of females were daily smokers, while $39 \%$ of males and $15 \%$ of females were occasional smokers.

The Indonesian Hou sehold Heal th Survey in 1995 was one of the biggest health survey performed in Indonesia wi th over 200,000 responden ts. ${ }^{6}$ Among i ts findings were the following:

1. . The prevalence of smoking in the male popu lation (10 years old and above) were $45 \%$ (daily smoker),

6.3\% (occasional smoker) and 3\% (former smoker). For the female population, the figures were 1.5\%, $0.5 \%$ and $0.2 \%$, respecti vely

2. For people 20 years of age and above, $61.2 \%$ were regu lar smokers, and $7.5 \%$ were occasional smokers. The prevalence in urban areas was $\mathrm{h}$ igher than the ru ral areas, and the prevalence decreased with higher levels of education.

3. For 20 year old and above, $47.8 \%$ of the respond en ts consu med 11- 20 cigarette per day, and $5.3 \%$ consumed more that 21 cigarettes per day. On average, 3.9 cigarettes were consumed by a smoker per day, or 1,427 cigarettes per year.

4. In urban populations, $12.1 \%$ of the respondents consumed filtered cigarettes, 3\% non-filtered cigarettes, 59.8\% smoked kretek cigarettes, 20.8\% smoked non-filtered $k$ retek cigarettes, $0.3 \%$ consumed cigars, 3.8\% rolled their own cigarettes, and $0.1 \%$ smoked tobacco using a pipe. The comparative numbers for the rural population are as follows: $11.6 \%, 2.8 \%, 33.7 \%, 24.9 \%, 0.6 \%$, $25.4 \%$ and $0.5 \%$ respecti vely.

Most of the tobacco consumed in Indonesia is in the form of cigarettes, and between $85 \%$ and $90 \%$ of all cigarettes smoked in Indonesia are $k$ reteks. The cigarette market share of $k$ reteks increased from about $30 \%$ in 1974 to about $90 \%$ in the 1990 s. Since the early 1970s, the per-capita adult (over 10 years of age) consumption of cigarettes (all forms) has more than doubled, from 500 to 1180 per adult. A survey carried out in Jakarta in 1981 estimated that each smoker consumed (on the average) twelve cigarettes each day. About $5 \%$ of all smokers smoke more than 20 cigarettes a day.

Table 2. Con sumption of manu factured cigarettes

\begin{tabular}{c|c}
\hline Year & Annu al average per adult $(15+)$ \\
\hline $1970-1972$ & 500 \\
$1980-1982$ & 950 \\
$1990-1992$ & 1180 \\
\hline
\end{tabular}

Tar levels in domestically grown Indonesian tobacco are high. In 1983, the average tar content of 18 brands of kretek cigarettes was $58.0 \mathrm{mg}$ (range 41 - 71), while the average nicotine content was $2.4 \mathrm{mg}$ (range 1.3 - 3.2). These are substantially higher than levels usually found in industrial ized countries. About 73\%

of man ufactured cigarettes are filter-tipped. Table 3 shows the tar, nicotine and Carbon Monoxide (CO) content of some kretek cigarettes in Indonesi a. It is particu larly interesting to compare the differences in the levels of the domestic and exported prod ucts of the same brands of cigarettes.

\section{Production and Economic Impact}

In 1990, 183,785 hectares of land were set aside for tobacco farming, which was down from 288,000 hectares in 1985. Between I \% and $2 \%$ of all arable land in Indonesia is used to grow tobacco. Between 1990 and 1992, Indonesia grew approximately 2.0\% of all the tobacco in the world. In 1994, Indonesia produced about 180,000 million cigarettes (about 
$3.3 \%$ of the world's production), which was up from 83,900 cigarettes in 1980. This increase in cigarette production is largely a reflection of the dramatic increase in the production of machine-made kretek (clove/tobacco mix) cigarettes that have largel $y$ replaced hand-to !led cigarerteL ${ }^{18}$

In 1992, Indonesi a imported 21,650 tons of raw tobacco (accou nting for $1.4 \%$ of all imports), while exporting 18,900 tons (about $1.1 \%$ of global exports). Indonesi a imported 15 million cigarettes and exported 15,000 million cigarettes, or $2.2 \%$ of global exports.
In 1990, the costs importing tobacco leaf and cigarettes amounted to US\$ 42.1 million $(0.1 \%$ of all import costs), compared with US\$ 17 million in 1985. In 1990, Indonesia earned an estimated US\$ 124.6 million from tobacco exports $(0.4 \%$ of all export earnings), up from approximately US\$ 48.2 million in 1985. On the other hand, Indonesian cigarettes production could be seen in figure 1, which showed the total production in the year 2000 was $237,206,000,000$ cigarettes a year, while in 1995 it was 204,365,000,000 a year.

Table 3. Tar, nicotine and CO content of kretek

\begin{tabular}{|c|c|c|c|c|}
\hline \multirow[t]{2}{*}{ No } & \multirow[t]{2}{*}{ Brand Name } & \multicolumn{3}{|c|}{ Concentration I Kretek (mg) } \\
\hline & & \multirow{2}{*}{$\begin{array}{c}\text { Nicotine } \\
3.17\end{array}$} & \multirow{2}{*}{$\begin{array}{c}\text { Tar } \\
57.02\end{array}$} & \multirow{2}{*}{$\begin{array}{c}\text { CO } \\
26.09\end{array}$} \\
\hline $\mathbf{I}$ & Gudan g Garam Internasion al & & & \\
\hline 2 & Gudang Garam Surya & 3.08 & 52.87 & 23.85 \\
\hline 3 & Bentoe! Intem asional & 2.35 & 47.37 & 21.51 \\
\hline 4 & Djarum Super & 2.31 & 53.98 & 27.61 \\
\hline 5 & Perdana Super & 2.42 & 61.09 & 36.95 \\
\hline 6 & Filtra lOOs & 2.17 & 49.84 & 25.24 \\
\hline 7 & Gudang Garam King Size 10 & 2.96 & 62.2 & 31.23 \\
\hline 8 & Dji Sam Soe & 2.24 & 42.29 & 25.05 \\
\hline 9 & Sampoerna A Mild & 1.26 & 18.05 & 9.84 \\
\hline 10 & Sampoerna A Exclusi ve & 1.91 & 34.13 & 16.37 \\
\hline II & Bentoe!Merah & 2.76 & 44.25 & 20.48 \\
\hline 12 & Wismilak & 3.13 & 56.48 & 23.92 \\
\hline 13 & Minak Jinggo & 2.07 & 53.4 & 25.59 \\
\hline 14 & Gudang Garam Surya 18 & 2.69 & 46.09 & 19.37 \\
\hline 15 & Bentoel Intenational Extra Lights & 1.91 & 33.24 & 21.52 \\
\hline \multirow[t]{2}{*}{16} & Bentoel International Mild & 1.23 & 41.06 & 19.21 \\
\hline & EXPORT & & & \\
\hline $\mathbf{I}$ & Dji Sam Soe & 0.75 & 11.92 & 4.19 \\
\hline 2 & Sampoerna A Exclusi ve & 0.8 & 11.11 & 6.37 \\
\hline 3 & Sampoerna A Mild & 0.63 & 10.78 & 7.32 \\
\hline
\end{tabular}




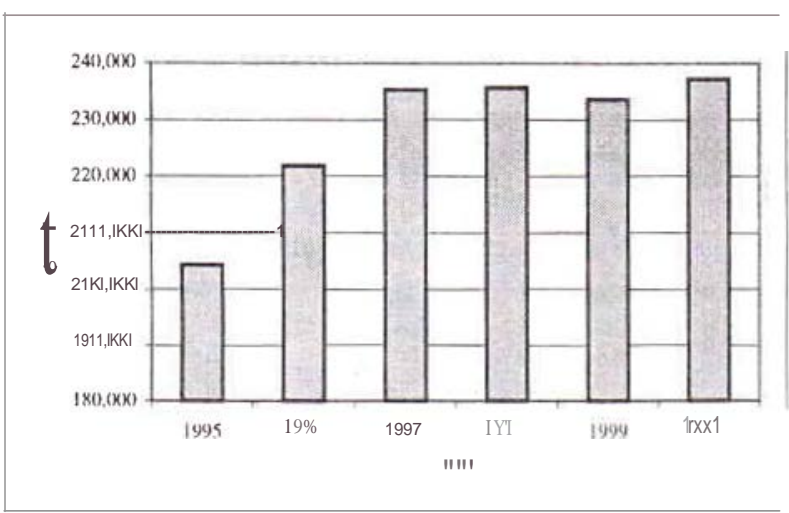

Figure 1. Indonesian cigarettes production

About 214,300 workers were engaged full-time in the tobacco-manufacturing ind ustry in 1989. The Indonesian kretek ind ustry ranks as the second largest employer after the Government. Figure 2 below showed tax fee target from cigarettes, which showed that in 1995/1996 it was only 3.3 quintillion (thousand billions), in 2000 it was increased to 10,3 thousand billions and in 2002 it was expected to be 22.4 thousand billions rupiah.

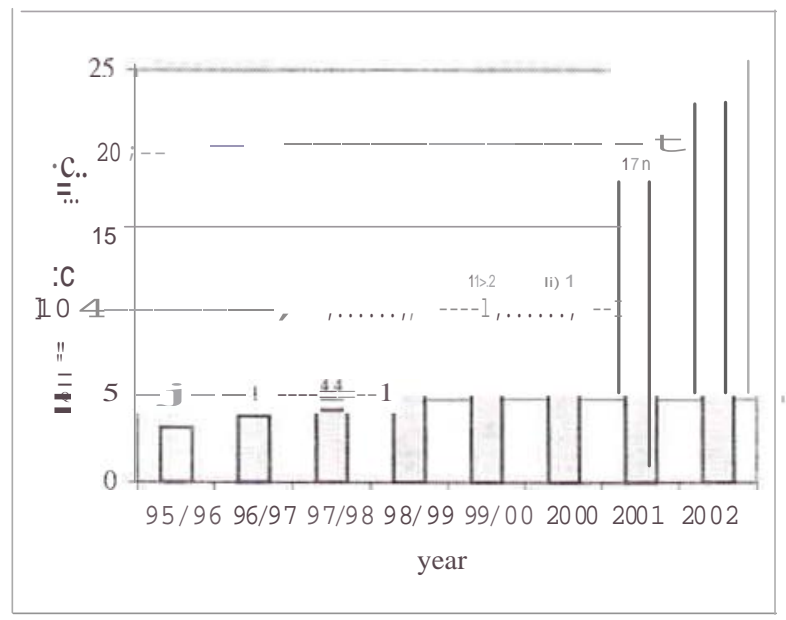

Figure 2. Taxfee target

A study by the National Institute of Health Research \& Development (Ministry of Health) attempted to analyze the economic impact of smoking in Indonesia.

With the GDP per capita in 1995 about US\$ 1,100, it is estimated that the macro economic loss for the country (government perspective) was in the amount of US\$ 9,806,423,000 (almost 10 billion US dollars) or about $50 \%$ of the total annual budget of the Ministry of Health .

Economic losses due to tobacco at the indi vidual/ family level can be divided into:
Direct Loss: loss of income due to illness and or disability
cost for medical treatment
Indirect Loss: loss of income due to illness and or disability
loss of income due to premature deaths
loss of income of family members, due to taking care of the patients

Estimated economic loss at community level for each lung cancer patient was as follows:

- Average cost for medical treatment -- US\$738.00.

- Average number of absenteeism per year due to hospitali zation -- 23 days.

- Thus, the lost income due to illness for one patien t is 23 X US\$ 5.00 -- US\$ 115.00 .

Loss of income of family members (due taking care of the patients) is also equal to US\$ $115.00 .{ }^{19}$

\section{Health Impact}

Reliable national mortality and morbidi ty data are scarce. However, whatever data are available al $l$ poi nt to an increase in the major chronic diseases associated with smoking. Esti mates suggest that tobaccoattributable mortali ty has risen from $1-3 \%$ of all deaths in 1980 to $3-4 \%$ in 1986 . This suggests that about 57,000 deaths each year (pri marily ma les) are already attributable to tobacco use, and this nu mber can be expected to increase dramatically over the next few decades.

A study of COPD and smoking in East Java provi nce found that 1,546 men (60.3\%) were smokers as compared to on ly $71(1.8 \%)$ of the women. COPD prevalence was $13.1 \%$ overall. In men it was $1 S .6 \%$, and in women the prevalence was $11.3 \%$. However, among male smokers the prevalence was $15.8 \%$. The relative risk of COPD in smokers was 1.02. Smoking and impaired PEFR (Peak Expiratory Flow Rate) were recorded in $12.4 \%$ of all respondents, and the results of the testing correlated well with the results from the questionnaire. Risk of impaired PEFR in smokers was 
1.04. Asthma was found in $8 \%$ at all respondents, while its prevalence in men was $9.6 \%$, in women $6.4 \%$, and in male smokers it was $9.2 \%$. The relative risk asthma in smokers was 0.88. All smokers smoked cigarettes; none of them professed to being a cigar smoker and only one was a pipe smoker. Kretek cigarettes were the most widel y smoked type of cigarette $(61.5 \%)$.

Only 270 (17.5\%) of the respondents had stopped smoking, but only 154 (57\%) had done so for more than 1 year, and only $12.6 \%$ of clove cigarette smokers have tried quitting. Most of the smokers (76.6\%) can be classified as light smokers, smoking less than 10 cigarettes I day. The nu mber of cigarettes I male smoker I day comes to 6.7 cigarettes. The prevalence of smokers goes up almost linearly with age, being $22.4 \%$ in the under 20 group to $75.6 \%$ in the over-50 group. Although paradoxically almost $40 \%$ of them started smoking in their late teens (38.5\%) and more than $75 \%$ began to smoke before the age of $25(77.2 \%){ }^{20}$

In a study on smoking and lung cancer in Jakarta, it was found that the relative risk to get Jung cancer for smokers 20 - 39 years of age was 6.76, and for those who had smoked for more than 40 years, the relative risk was 9.37. They fou nd a significant relationship between smoking and lung cancer among their male respondents, but not among the females. The doseresponse impact was also discovered to be significantly among their male respondent. ${ }^{21}$

Another survey in 1993 assessed effects of passive smoking on pregnancy outcomes in Jakarta. The study concluded that odds ratio for a pregnant women exposed to passive smoking having a low birth-weight infants was $2.3 .^{22}$

\section{Prevalence Among Youth}

A 1985 survey of primary schoolchildren in Jakarta found that $49 \%$ of the boys and $9 \%$ of the girls aged 10-14 were daily smokers. However, a study in Jakarta in 1990 reported that on!y $1 \%$ of the $11-14$ year olds, $9 \%$ of the 15 year olds, and $6 \%$ of the 16 year olds were daily smokers, although the figures for occasional smokers were $15 \%, 22 \%$, and $44 \%$, respectively. The latter study also revealed that $9 \%$ of the children started smoking when under 10 years old, $8 \%$ at the age of $11,18 \%$ at age $12,23 \%$ at age 13 , and $40 \%$ at age $14-16$. The vast majority (95\%) smoked kreteks, and $72 \%$ reported that their parents did not know that they smoked. ${ }^{13}$

The meta-analysis study done by "LM 3" found that in both current and former smokers, most initiated smoking between 10 and 29 years of age; there was no clear difference between males and females. However, the study did show that male teenagers start smoking earlier, while females tend to wait to try smoking after the age of 20, but all were at the young group. This was happened in the severity of smoking, which both groups together majority were still stay in the mild group, i.e. less than $200 .^{14}$

This study also concluded that teenager smokers were found in the proportion ranged from $12.8 \%$ to $27,7 \%$ in males, and among females were $0.64 \%$ to $1 \%$. Either in current or ex-smokers the age of smoking initiation were quite young, since the highest proportion was found in 10 to less than 30 years old. In males there were $81,34 \%$ of current smokers, and $77,80 \%$ of ex smokers, while in females looked likely to be lower, $49.05 \%$ of current smokers, and $48.30 \%$ of ex smokers. Females tend to start to smoke at the older age.

Table 4. The Age of Smoking Initiation among Smokers

\begin{tabular}{l|rrr|rrr}
\cline { 1 - 6 } $\begin{array}{l}\text { The age of smoking } \\
\text { initiation (years) }\end{array}$ & \multicolumn{3}{c|}{ Current smokers } & \multicolumn{3}{c}{ Ex smokers } \\
\hline & Males & Females & Total & Males & Females & Total \\
\hline$<10$ & 1,15 & 1,93 & 1,26 & 1,08 & 0,85 & 1,03 \\
$10-19$ & 44,20 & 22,86 & 41,14 & 43,53 & 22,88 & 39,35 \\
$20-29$ & 37,14 & 26,23 & 35,58 & 34,27 & 25,42 & 32,47 \\
$30-39$ & 6,57 & 16,37 & 7,98 & 6,90 & 13,56 & 8,25 \\
$40-49$ & 1,85 & 9,63 & 2,97 & 1,08 & 11,86 & 3,27 \\
$50-59$ & 0,71 & 6,38 & 1,52 & 1,29 & 6,78 & 2,41 \\
60 and up & 1,69 & 2,29 & 1,78 & 1,51 & 0,85 & 1,38 \\
\hline
\end{tabular}


The Indonesian Household Health Survey 1995 found that the youngest age to start smoking was 5 years old. While a fair number of respondents started smoking between the ages of 10 and 14 years of age or between 21 and 25 years of age, most of the respondents started smoking between 15 and 19 years old. Only a very small proportion of the respondents started smoking between 26 - 30 years old. ${ }^{6}$

Another survey by the University of Indonesia showed that you ng adult men (when compared to young adult women) are far more likely to use substances that increase health risks. For example, $81.1 \%$ of young adult men have smoked cigarettes compared to only $8.0 \%$ of women. Similarly, $27.9 \%$ of men say they have drunk alcoholic beverages (compared to only $1.0 \%$ among women), and a history of recreational drugs was reported in $8.5 \%$ of the men and only $0.5 \%$ for women. In general, the consumption of alcohol and recreational drug use is higher among older respondents (aged 20-24 years of age), in urban areas, and among the more highly educated. In contrast, does not vary significantly with age, u rban vs. ru ral setting, and their level of education. While men who have been married report higher levels of smoking and drinking, single males are slightly more likely to have used recreational dru gs $(8.6 \%$ of single men compared to $7.2 \%$ of married men).

When asked if smoking, drinking, and drug u se are harmful acti vities, nearly all respondents said yes. Many young adults who are u sing these substances say they would like to stop. Among youth who are currently smoking, $83.2 \%$ would prefer to give up the habit. Young adult smokers who were interviewed are qu ite heavy consumers of cigarettes; men average 7.6 cigarettes and women 3.7 cigarettes each day. ${ }^{23}$

Another survey in Bali found that $15 \%$ of pri mary high school students (14-15 years old) are smokers. Data from 1219 primary and secondary school in Bandung (1998) showed that 32,33\% had tried smoking, and that $12.3 \%$ are daily smokers. Another survey on street vendor children in 1998 found that $78.21 \%$ of those children are smokers in Semarang and $58 \%$ of them in Bandung. ${ }^{24}$

Table S. Smoking attitude ${ }^{23}$

\begin{tabular}{|c|c|c|c|c|}
\hline & & \multicolumn{2}{|c|}{ Sex of Respondent } & \multirow[t]{2}{*}{ Total } \\
\hline & & Male & Female & \\
\hline \multirow[t]{2}{*}{ Do you thinks smoking is harmfuP } & Yes & $97.8 \%$ & $96.8 \%$ & $97.3 \%$ \\
\hline & No & $2.2 \%$ & $3.2 \%$ & $2.7 \%$ \\
\hline Total Respondents: & -- & 4219 & 3854 & 8073 \\
\hline \multirow[t]{2}{*}{ Have you ever smoked? } & Yes & $81.9 \%$ & $8.0 \%$ & $46.6 \%$ \\
\hline & No & $18.1 \%$ & $92.0 \%$ & $53.4 \%$ \\
\hline Total Respondents : & - & 4221 & 3858 & 8079 \\
\hline \multirow[t]{2}{*}{ Are you just "experimenting ?" } & Yes & $37.8 \%$ & $89.4 \%$ & $42.1 \%$ \\
\hline & No & $62.2 \%$ & $10.6 \%$ & $57.9 \%$ \\
\hline Total Respondents: & -- & 3456 & 308 & 3764 \\
\hline \multirow[t]{3}{*}{ Do you smoke now? } & Yes, regularly & $78.2 \%$ & $17.9 \%$ & $77.3 \%$ \\
\hline & Yes, sometimes & $20.5 \%$ & $44.4 \%$ & $20.9 \%$ \\
\hline & No & $1.3 \%$ & $37.7 \%$ & $1.8 \%$ \\
\hline Total Respondents: & -- & 2152 & 33 & 2185 \\
\hline \multirow[t]{2}{*}{ Do you want to stop smoking? } & Yes & $83.1 \%$ & $94.3 \%$ & $83.2 \%$ \\
\hline & No & $16.9 \%$ & $5.7 \%$ & $16.8 \%$ \\
\hline Total Respondents : & -- & 2122 & 20 & 2143 \\
\hline \multirow[t]{2}{*}{ Have you tried to stop smoking? } & Yes & $85.0 \%$ & $87.9 \%$ & $85.0 \%$ \\
\hline & No & $15.0 \%$ & $12.1 \%$ & $15.0 \%$ \\
\hline Total Respondents & -- & 1763 & 19 & 1783 \\
\hline
\end{tabular}


A survey was conducted by the Indonesian Smoking Control Foundation ("LM3") to determine the smoking pattern among children street vendors in Jakarta. This survey interviewed 250 street vendors in Jakarta, all below 14 years of age. $20.27 \%$ of these child ren sell cigarettes. $9.57 \%$ of these children started smoking before the age of 10 years, $25.36 \%$ started between 10 - 11 years old, 52.63\% start smoking at 12 13 years old and $14.44 \%$ start smoking at 14 years of age. Of these street vendor children, $40.6 \%$ of them said they planned to continue smoking in the future. Their reasons to start smoking were "for fun," it "tastes good," "proud" to be smoker, and to feel "macho." $54.9 \%$ of the respond ents consumed less than $19 \%$ of thei $\mathrm{r}$ income to bu y cigarettes, $37.74 \%$ respondent consumed $10-20 \%$ of their income, $5.03 \%$ consumed 2 1-30\%, J.89\% consumed $31-40 \%$ and $1.26 \%$ respondent consumed more than $40 \%$ of their income to buy cigarettes. $77 \%$ of the group actually felt afraid that their parents would learn that their children smoked cigarettes. $86.98 \%$ of them knew that smoking was dangerous, but only $40.60 \%$ of them felt that had any current health problem related to their smoking habit. Of these, $71.08 \%$ experienced coughing and $12.05 \%$ described dyspnea. About $70.97 \%$ of respondents said that almost all street vendor children. are active smokers. ${ }^{25}$

Another preliminary non random survey by the Indonesian Smoking Control Fou nd ati on ("LM 3") focused on students from one of the top-ranked high schools in Jakarta namely SMUN 8. The responden ts were 95 students, of which only $7.4 \%$ were smokers and $6.3 \%$ were former smokers. On the other hand, it is estimated that the smoking prevalen ce in other high schools is much higher compared to this finding. A similar survey was also conducted on sen ior year medical and dentist students, with 71 respondents; $5.6 \%$ of them are current smokers, and another 5.6\% . are former smokers. In contrast to those data, a survey on students at a nursing academy found that only $1.1 \%$ of these students are active smokers, and $4.3 \%$ are former smokers. Lessons in school were felt to be most important source of information about the harmful effects of smoking by $41.5 \%$ of the high school students respondents, $48 \%$ medical and dentist students and $38.2 \%$ of nursing academy students. This survey will be continued and extended in the near future. ${ }^{26}$

A survey on the kn owledge and attitudes about cigarette smoking among schoolchildr en in central Jakarta concluded that: ${ }^{27}$
1. The basic knowledge concerning cigarette smoking of schoolchildren in the slum and nonslum areas of Central Jakarta is sufficient, but it need s to be broadened.

2. The attitude of schoolchildren in both the slum and non-slum areas of Central Jakarta is generally against cigarette smoking.

3. Advertisements, through television, radio and other pu blic media (posters, banners, billboards) are the most persuasi ve sources of information used to promote cigarette smoking. Efforts should be made to eliminate these media from the schoolchildren's surroundings, especially in the neighbourhood of the schools.

4. Educational programs on television and direct partici pation by healthcare personnel are the most impressive sources of information concerning the hazards of smoking, but at the present time, these address only a very limited audience. Efforts should be made to increase the role of educational television program $s$ and the use of health personnel as the source of information concerning the hazards of cigarette smoking.

5. The role of friends, families and school teachers as sources of informati on on the hazards of smoking is still very limited. Efforts should be made to increase the role played by these groups for them to become more effective in delivering the nonsmoking message. Social activities at the schools such as non -smoking gatherings with parent s, teachers, and studen ts should be encouraged to promote the idea of non-smoking .

6. Radio and printed media are very under-utilised as sources of information concerning smoking hazard s. Attracti ve programs for children need to be designed so that children can get accurate information about the harmful effects of cigarettes and smoking.

\section{Summary}

Smoking is an importan t problem in Indonesia. The smoking prevalence in male population is more then $60 \%$. The relativel y low prevalence rate in female (about 5\%) may be due to traditional social restrictions, but it is safe to assume that the smoking prevalence in women will be increasing in the near future. Up to $f O \%$ of male teenagers smoke. The majority of smokers start smoking between 15 and 20 years of age, although some children start smoking as 
young as 5 years old. Kretek clove cigarettes are the most popular type consumed by smokers in Indonesia. In fact, most of these kretek cigarettes have very high tar and nicotine content.

At least five factors complicate smoking-control programs in Indonesia.

One, it is estimated that about 12 million people are supported by tobacco-related industries. This includes tobacco and clove farmers, workers in tobacco factories, the distributors, shops and all the way down to the children street vendors; and one must add all of their families. Second, the cigarette industry is an important source of tax reven ues for Indonesia. The income that the government receives will surely be a important consideration while making any policies regarding to smoking-control programs.

Third, there is insufficient scientific research on smoking and health in the Indonesian population. Most doctors and health professionals use literature from abroad when designing health-education act1v1ties. Discussions with respectful medical specialists found out that there are quite few research being done in the field of smoking and heath. Fu rthermore, since common infections and tropical diseases are still very prevalent in Indonesia, they (probably understandably) receive more attention compared to research on tobacco and health.

Fou rth, smoking is socially accepted by most Indonesians. "Cigarette money" is a slang phrase commonly used for giving somebody a tip. During social gatherings, in urban as well as in rural areas, cigarettes are usually served. Asking somebody not to smoke is still sometimes considered impolite or perhaps even "foreign" behavior. Fifth, the political commitment from decision makers in the government is not yet strong enough.

To strengthen the smoking-control program in Indonesia, several things are needed. First, health education for the general public is very important. Many kinds of public media must be used, since cigarette advertising is actively using all of them. In fact, the knowledge of the general population about smoking is still quite limited. In most medical and nursing school curricula, there are no special classes for smoking and health. Improving the knowledge about smoking, its impact on health, the economy and the many other aspects of the problem would be an important first step toward an effective smokingcontrol program in Indonesia.

Secondly, every segment in the society must be organized and utilized optimally. Government has a responsibility of coordination and regulation, and professional organization and NGOs can and already play important roles in any smoking-control program . In fact, they can play even more effective roles if allowed to work in a conducive environment.

Third, regulation and laws in the field of smoking should be enacted and firmly implemented. These regulations should at least include policies on advertisement, tar and nicotine content, defining smokefree area, tobacco tax and fiscal issues, protection for vulnerable groups (such as women and children), etc. Many considerations must be keep in mind, but in the end, it is the health of the people of Indonesia who should receive the highest priority .

Fourth, especially for a tobacco and clove-producing country like Indonesia, a diversification of the tobacco industry should be started. There must be a way to find a smooth transition between the tobaccodependent economy and one which is health y. Fifth , political commitment from government and parliament should be encouraged. They play a critical role in the decision-making process in the country. NGOs and other public organization should lobby hard to obtain this important political commitment.

Sixth, there are still much to be done in the field of research. Epidemiologic al research must be improved. Indonesia is a h uge country with more than 200 million inhabitants in hundreds ethnic groups spread over 17,000 islands. Special epidemiological techniqu es are needed to obtain reliable data that represent $\mathrm{s}$ the whole country. The health-related economic research is also needed. "Money talks," and having good information will accomplish a lot in discussions about economic policies.

International collaboration can, indeed, play an important role in smoking control. This kind of collaboration does not only cover researches, but it also serves as a kind of bench-marking of activities between countries in various aspects of their respective smoking-control programs. Success stories from one country could provide moti vation for neighboring countries. On the other hand, failure of one part of a country's program could serve as a good 
example for another. Smoking is, after all, a global problem, and only a global solution can effectively deal with it.

\section{Acknowledgment}

The author wou ld like to thanks Dr John W Aldis MD for his val uable advice i n the presen tation of this article.

\section{REFERENCES}

1. Central Bureau of Statistics. Demographic and Health Survey 1997. Jakarta, Central Bu reau of Statistics, 1998: 1-3.

2. National Household Health Survey 1992 (Indonesian). Jakarta, NI HRD Mini stry of Heal th Republic of Indonesia, J 992

3. Interna ti onal Medi cal Fou ndation of Japan. SEAMIC Heal th Statistics 1998. Tokyo, IMFJ, 1998.

4. Mi nistry of Health Repu blic of Indonesia. Survey on Eye and E-N-T Heal th 1994-1996 in 7 Provi nces, $\mathrm{MOH}$, RI (I ndonesian). Jakarta: NlHRD Mi nistry of Health Republic of Indonesi a, J 996.

5. Mini try of Health Republic of Indonesia. Indonesian Fami ly Life Survey 1993 in 13 Provinces (Indonesian). LD-FEU I, Rand Co, 1993.

6. Mini stry of Health Republic of Indonesi a. National Hou sehold Su rvey, Mod ule on Susenas, 1995, in 5 Provi nces (I ndonesian). NIHRD Ministry of Heal th Repu bl ic of Indon esia, 1996

7. FKM UI. Prospecti ve Study on Public Health, Pasar Reba, Ci payu ng \& Ciracas, East Jakarta: (I ndonesian). Jakarta: FK MUI, 1993/94.

8. Notoatmodjo S, Soeki djo, Siregar K N, Wi bowo A. Smoking habit and its soci oeconomic aspects in Jakarta (I ndonesian). Jakarta: FKMUI, 1981.

9. Tanjung, Judin P. Effect on Smoking Deceased Program among the smoker-workers i n St.Carolus Hospi tal Jakarta (Indonesian). Jakarta: FKMUI, 1995.

I 0. Soetiarto, Farida. Relationshi p between habit on cloves smoking and dental destruction, among the dri vers of PPD company in Jakarta (Indonesian). Jakarta, FK MUI 1992.

11 . Hoepoedio RS. Action on Smoking: Compi l ation of papers on Cancer Problem (Indonesi an). Jakart a: 198 I .
12. Syafranelsar. Proportion of Smoker among the male employees in the office of Ditjen Binkesmas (Indonesian). Jakarta: FKUI, 1995.

13. Shehbubakar, Sukaenah. Study on knowledge, attitude and behaviour on smoking, among the pupils of elementary school grades $\mathrm{V}$ and VI in East Jakarta (Indonesian). Jakarta: Faculty of Medicine, Uni versity of Indonesia, 1992.

14. Indonesian Smoking Control Foundation. Meta-Analysis Smoking Pattern in 14 Provi nces in Indonesia (Indonesian). Jakarta: Indonesi an Smoking Control Foundation ("LM3"), 1998.

15. National Household Health Survey 1980 (Indonesian). Jakarta: NIHRD Ministry of Heal th Republic of Indonesi a, 1980

J 6. World Health Organization. Geneva, Tobacco or Health: A Global Status Report. World Health Organization, 1997.

1 7. National Household Health Survey 1980 (Indonesian). Jakarta, NIHRD Ministry of Heal th Republic of Indonesia, 1980

J 8 Aditama TY. Tobacco and Health (Indonesian). Jakarta, UI Press 1997.

1 9. Kosen S. Anal ysis of Current Economic Impact (Government and Community Perspective) of Smoking i n Indonesi a. Jakarta: A Report Su bmi tted to WHO Indonesi a. NIHRD Ministry of Heal th Repu blic of Indonesi a, 1998.

20. Benyamin M. Smoking: An East Java COPD Survey. Surabaya: Department of Pu l monology $\mathrm{Ai}$ rlangga Uni versity School of Medici ne, 1990.

21. Suryanto E, Yusuf A, Hudoyo A. Smoking and Lu ng Cancer (Indonesi an). MKI 1986; 36: 369-74.

22. Tanuwijaya S. Youth Epidemiology Problems (Indonesian). National Congress of Pediatrician. Jakarta, 1999.

23 Demographic Foundation, University of Indonesia . Reproducti ve You th Health (Indonesian). Jakarta, 1992.

24. Adisasmi ta A. Effect of Passi ve Smoking on Pregnancy Ou tcome (Indonesian). Jakarta: FKMUI, 1993.

25. Wijayata M. Smoking Pattern Among Street Vendor Children (Indonesian). Jakarta, Indonesian Smoking Control Foundation ("LM3"), 1995.

26. Tjandra YA. Smoking Habit in High School, Dental and Medical School (Indonesian). Jakarta, Indonesian Smoking Control Fou ndation ("LM3"), 1995.

27. N, T. (2017). Mau nanya dong dok. [online] Mau nanya dong dok. Available at: https://nanyadongdok.blogspot.com [Accessed 2 Jul. 2017]. 